\title{
Ways of doing: exercising dialogues between design, handicraft and social innovation
}

\author{
Flávia Wanderley Pereira de Lira ${ }^{1, a}$, Leonardo Augusto Gómez Castillo ${ }^{1}$, Maria das Vitórias Negreiros do Amaral ${ }^{2}$ \\ ${ }^{1}$ Universidade Federal de Pernambuco - UFPE, Design Department, 1235 Prof. Moraes Rego ave, - Cidade Universitária, zip code: \\ 50670-901, Recife, PE, Brasil \\ ${ }^{2}$ Universidade Federal de Pernambuco - UFPE, Visual ArtsDepartment, 1235 Prof. Moraes Rego ave, - Cidade Universitária, zip code: \\ 50670-901, Recife, PE, Brasil
}

\begin{abstract}
This article deals with the ways of doing of a handicraft group, that is, how they act, how they use memory and traditions, the inputs in their natural environment, of artifacts, imagination and their bodies; How they articulate themselves with their abilities. For this article, we cut the research Design and Handicraft: Sharing Paths for Social Innovation, held between August 2014 and October 2016, where we investigated the group MulheresFatechas, formed by fisherwomen-shellfish-artists-artisans, after participating in a design project to promote handicrafts. The objective of the research was to understand how a design project impacted the construction of knowledge, empowerment and the relationship between the group and the environment. To do so, we used ethnography and the theoretical basis of Anthropology of the Imaginary in order to understand the symbolic and organizing relations of the group (MulheresFatechas) from recurrent images in photographic records and videos, interviews, documents, drawings, meetings and life experiences at the field. The methodology adopted came from a perspective of practical performance of the designer next to the group and they made bridges/dialogues with the theoretical contribution of the Social Sciences and Social Innovation, resulting in the construction of the more general aspects of the group's ways of doing, namely: learning, cooperation and engagement, and their respective indicators. Therefore, in the article, when we consider how the subject cooperates with his group/network from the reflected, articulated, constructed and realized actions in their context, we aim to discuss the relations between language/imagination and the knowledge acquired with the corporal practices; The rituals of cooperation as a way of doing handicrafts; and the making of poetry linked to the engagement involving artists-artisans, designers and the community, contributing / building the constructions between the realities of design, handicrafts and social innovation.
\end{abstract}

Keywords. Arts and Crafts. Design. Imaginarium. Social innovation. Qualitative indicators.

Currently, the search for more sustainable life alternatives that reduce the impacts caused to the environment, especially the impacts related to the social and natural sphere, from the current forms of production, consumption and disposal, is a matter of urgency. In this perspective, Manzini (2008) affirms that "designers have been and still are 'part of the problem'," however they can and should be "part of the solution". Manzini exposes the potentiality of a profession, still young, born in the context of industrialization, and whose essence is to face the challenges that present themselves in time/space of constant updatings.

We can say, then, that the designers' challenge is no longer to design products for the available technologies, but to review the processes, a re-connection of knowledges, is to collaborate in the construction of more respectful and responsible ways of life, regenerators of

${ }^{\mathrm{a}}$ Corresponding author: flaviawlira1@gmail.com the subject ${ }^{1}$ qualities ${ }^{2}$ and the environment where he is inserted.

In practice, a first step that can be taken in this direction is related to the activation of local contexts, triggering actions that involve the different social actors, with the purpose of converting the problems found in solutions into multiple spheres - social, ecological, cultural, economic. Within this process of activation, we

\footnotetext{
${ }^{1}$ The subject, in this case, is a historical subject, built by the dialogue that elaborates with the world around himself and is constituted of these (socio-cultural) relations that he produces with that externality that surrounds him.

${ }^{2}$ Understanding by quality "the way in which different systems (natural, artificial, physical and sociocultural, market goods and common goods) interrelate" (MANZINI 2008).
} 
understand that one possibility lies in the design projects for handicraft as mediators of the man/womanenvironment-space-time relationship. These projects aim to contribute to the (re)valorization and enhancement of local aspects (raw materials, technologies, stories, memories, knowledge, etc.) structured in the processes (production, management and marketing) that figure the handicraft.

Groups of artisanal production exercise relations with nature, with tradition and with identity during the production of their material culture. They re-organize, reproduce, resignify themselves, characterize and differentiate themselves from their visions about reality and the culture where they are immersed, considering their time and space. Similarly, both designers and handicraft-producing groups need to stock up on the sensitivities of others to act, they must be inserted "(...) in a process of correspondence, of participation, that privileges the collective body" (MAFFESOLI 1998), so, they need to exercise their social role more aware of themselves and of what they culturally produce.

Starting from these conditions-reflections, the article presents ways of doing that composes the dissertation Design and Handicraft: Sharing Paths for Social Innovation, from the Post Graduate Program in Design of UFPE, through the Innovation, Design and Sustainability Research Group. This research is associated to the field project: Design Sustentável Paulista Criativa ${ }^{3}$, carried out from October 2014 to May 2015, which gave practical support to it. The aforementioned project took shape when a multidisciplinary group (from the fields of design, creative economics and management) met in 2014 to discuss and "draw" an action that focused on the development of women's handicrafts in a Fishermen's Colony, in Paulista, metropolitan region of Recife, in Pernambuco-Brazil, through design and entrepreneurship. Most of the participants in the MulheresFatechas $^{4}$ group were fisherwomen, other artisanal artists, all of whom were associated with the Fishermen's Colony and often helped their husbands in

\footnotetext{
3 The Design Sustentável Paulista Criativa project, included in the Renner's (department store) announcement, had the partnership of the ADM \& TEC Institute of Administration and Technology as executive entity, with the support of the Secretariat of Economic Development, the Secretariat of Tourism and the Special Secretariat of Politics For the Women of Paulista, in what concerns the contacts and support to the local actions, and of the Colony of Fishermen with the assignment of the space for the execution of the workshops and meetings.
}

\footnotetext{
4 "Fatecha" means anchor and goes back to the indigenous artisan anchor made of wood, rope and stone by fishermen, forming part of the group concept. The MulheresFatechas are women anchored with the environment, with their history and memory.
}

fishing. Since it was the group's first contact with design, we assumed this field for research in order to understand the action impacts.

\section{Methodology}

Methodologically, the article uses a clipping of two moments of the field, before the design workshops and after one year of project completion and exit of the designers, in order to understand how the projects that are performed as collective and collaborative practices between designers and handicraft production groups can contribute/elucidate ways of social innovation. In this way, we focused on the reverberation of the interrelationships built between the designers and the group of fisherwomen-shellfish-artists-artisans and on how these relations affected the living conditions of all who participated during the process, in the continuity and in the unfolding of their ways of doing and knowing.

In the article, we make a subjective interpretation of participant observation in the context of the MulheresFatechas group, their relationship with themselves, their network of partnership and the environment in which they live and work. In order to do so, we consider the elements that are repeated in an obsessive way and which establish a kind of meaning (constellation of images) that, in association with the theoretical reference, relates the language/imagination to the knowledge acquired with the corporal practices; images linked to the rituals of cooperation; and, the making of poetry. These constellations, in turn, converged on the more general aspects of the group's ways of doing: learning, cooperation and engagement, and their respective indicators.

The article is based on Social Sciences theorists such as Arnold van Gennep (2011), Michel Maffesoli (1998), Richard Sennett (2012, 2013), Paulo Freire (1979, 1980, 1996); And the bridges construction with social innovation, through Ézio Manzini (2008). However, it is a look at design, whose resources, choices of works and authors were happening, backed up and requested by what emerged in the context, as the research progressed and the images emerged from the field.

\section{Mulheres Fatechas group}

In our first meeting, we noticed the group of women, shellfish and fishing artisans quite familiar. There were mother and daughter, six sisters, mothers taking their little children, there were friends, neighbors. In all, 24 women were present at the beginning of the project, who said that they were hardworking, extroverted and cheerful, expressing their desire to learn and grow, to interact and to be part of the collective. They had fishing and shellfish as a tradition passed by their mothers, fathers and their fishermen grandfathers, since they were 
very small. In their speeches, they translated the mangrove as the "backyard"; They talked about the life experienced "within the tide"; They presented their neighborhood as partnership. Their fruits/children/grandchildren were mixed with the fruits of the mangrove. They were also children and grandchildren of the mangrove.

According to the socio-economic data collected by ADM \& TEC for the Design Sustentável Paulista Criativa project (2014), the majority of shellfish women and fisherwomen were between 40 and 60 years old, 5\% white, $10 \%$ black and $85 \%$ brown and had studied until the fourth grade of Elementary School. The shellfish women had a very low monthly average income, around R\$ 200.00. The fisherwomen, whose incomes didn't exceed two minimum wages in good times, needed to look for alternatives to support their families' livelihoods mainly during periods of low fishing.

This was the scenario of the project and, later, of the research that unfolded in the ways of doing of the group studied.

\section{Collaborating with Social Innovation}

As the time we sew the terms of research and Social Innovation, theorized by Manzini (2008), we started from constructions based on social learning processes carried out in the local context; In the engagement that involves everybody in the promotion of difference and cooperation as a way to broaden our ability to interact in a network and the environment that surrounds us.

Front the field, we could observe a listening-dialogue with possibilities to promote:

- The use of systemic intelligence (MANZINI 2008) related to the "(...) process of social learning ... through the development of an ability to learn through the experience (...) stimulating personal and reinforcing the social fabric "(MANZINI 2008).

- The active welfare (MANZINI 2008), a term that refers to an integrating condition of welfare that "... emerges from the dynamic relation between functions and capabilities, between what a person could be and do, and what he or she really knows. In this way, articulating the solutions available in a given context with the personal resources of someone who acts in the same context "(MANZINI 2008).

Therefore, from the key themes that emerged from the field, we present the strength aspects of ways of doing, through which the relationships between the fishermen-shellfish-artists-artisans and designers (the subjects of the research) and the context circulated; As well as their respective indicators.

They are:
1. LEARNING aspect, that deals with the relations of exchange and instructive experiences for the subject, where "the one who teaches, learns in teaching and the one who learns, teaches in learning" (FREIRE 1996). The subject interacts with the environment, the nature, the object, etc.) retroactively, from the experimentation and consciousness/awareness of the process. In this way, Sennett (2013) draws attention to the creative processes that arise from the simultaneous and retroactive relationship between idea and matter, between the imaginary and the body of the one who makes/produces. For this author, moments of creation are, in fact, anchored in the praxis of the subject, and there finement of the skills is given by the consideration of difficulties and inaccuracies - resistance and ambiguity, by listening and by dialogue, in search of quality - of a well done job.

Table 1. Learning indicators.

\begin{tabular}{|c|c|}
\hline Indicator & $\begin{array}{l}\text { Recognition and knowledge degree of techniques, } \\
\text { knowledge, natural inputs of network/group }\end{array}$ \\
\hline Definition & $\begin{array}{l}\text { This indicator treats the construction of knowledge } \\
\text { realized by the group from the knowledge recognition, } \\
\text { techniques, natural inputs etc. and from design projects }\end{array}$ \\
\hline $\begin{array}{l}\text { Addressed } \\
\text { issues }\end{array}$ & $\begin{array}{l}\text { - What craft techniques did you know before the design } \\
\text { project and which do you know today from the project? } \\
\text { - How did you use the natural inputs (shellfish shells, } \\
\text { scales, coconuts bark) before the design project and } \\
\text { how do you use it today after the project? } \\
\text { - What has been done/tried by the group for handicrafts? } \\
\text { And what has not yet been and the group feel like } \\
\text { experimenting? }\end{array}$ \\
\hline Indicator & $\begin{array}{l}\text { Degree of the subject/group/product/technique } \\
\text { transformation }\end{array}$ \\
\hline Definition & $\begin{array}{l}\text { This indicator deals with the condition of the group in } \\
\text { transforming themselves and transforming their } \\
\text { practices from the awareness of the relationship } \\
\text { existing in the field }\end{array}$ \\
\hline & $\begin{array}{l}\text { - How did you see each other/ourselves before the } \\
\text { design project? And how do you see each other/ } \\
\text { ourselves today, from the exchanges made during/after } \\
\text { the project? } \\
\text { - How did you see the handicrafts before the design } \\
\text { project? And how do you see today, from the changes } \\
\text { made in the project? } \\
\text { - How did you see the techniques you knew and used } \\
\text { before the design project? And how do you see today, } \\
\text { from the changes made during/after the project? }\end{array}$ \\
\hline Indicator & Degree of integration to the local context \\
\hline Definition & $\begin{array}{l}\text { This indicator seeks to present a group consciousness } \\
\text { embodied in the local context and the relationship } \\
\text { unleashed from that consciousness }\end{array}$ \\
\hline $\begin{array}{l}\text { Addressed } \\
\text { issues }\end{array}$ & $\begin{array}{l}\text { - How do you guys make a dialogue with the city } \\
\text { where you live and work? How do you guys produce } \\
\text { dialogue with the city? } \\
\text { - How does the handicraft show the characteristics of } \\
\text { the place where you live and work? } \\
\text { - How and when do you guys usually observe the place } \\
\text { where you live and work? }\end{array}$ \\
\hline
\end{tabular}

The learning aspect and its indicators characterize a composite connection between training-education 
(SENNETT 2012; FREIRE 1996) and the systemic intelligence (MANZINI 2008), in the search for learning related to the processes-paths to the result-quality.

2. COOPERATION aspect, that deals with the harmonization relationship between inequalities through interaction. For Sennett (2013), the relations between subjects will be more productive if they operate together, because there is always the possibility of learning something from the other, even if it diverges. Sennett (2003) notes reciprocity, pleasure, and empathy as characteristics that reach the subject in greater depth during co-operation. In addition to Sennett, Freire (1979) observes that in the search of his own learning, the subject must commune with other "consciences". It deals with the "close relationship between communion and search" (Freire 1979), through communication.

Table 2. Cooperation indicators.

\begin{tabular}{|c|c|}
\hline Indicator & $\begin{array}{l}\text { Degree of sharing between subject and group, between } \\
\text { group and context }\end{array}$ \\
\hline Definition & $\begin{array}{l}\text { This indicator tries to understand how the group shares } \\
\text { its knowledge, knowings, inputs, spaces, articulations } \\
\text { with its environment (telling stories, memories, } \\
\text { remembering techniques, describing their spaces and } \\
\text { their speech) }\end{array}$ \\
\hline $\begin{array}{l}\text { Addressed } \\
\text { issues }\end{array}$ & $\begin{array}{l}\text { - What do you guys usually share with the group? } \\
\text { - What does the group usually share with each } \\
\text { participant? } \\
\text { - How does each participant in the group share } \\
\text { information and knowledge? } \\
\text { - How do you guys usually work? In Group? } \\
\text { Individually? }\end{array}$ \\
\hline Indicator & $\begin{array}{l}\text { Degree of reciprocity between the subject and the } \\
\text { group/between the group and the context }\end{array}$ \\
\hline Definition & $\begin{array}{l}\text { This indicator deals with the matching condition and } \\
\text { attunement of the group in the feedback relationship } \\
\text { both internally, within itself and the context in which } \\
\text { it's inserted }\end{array}$ \\
\hline $\begin{array}{l}\text { Addressed } \\
\text { issues }\end{array}$ & $\begin{array}{l}\text { - How does the group answer/correspond when you } \\
\text { express yourself? } \\
\text { - How do you receive criticism (positive and negative) } \\
\text { from the group? } \\
\text { - How do you usually express your criticisms (positive } \\
\text { and negative)/observations to the group? } \\
\text { - How do you feel when you are not understood by the } \\
\text { group? }\end{array}$ \\
\hline Indicator & $\begin{array}{l}\text { Degree of interaction between the subject and the } \\
\text { group/between the group and the context }\end{array}$ \\
\hline Definition & $\begin{array}{l}\text { This indicator deals with the group communication/ } \\
\text { dialogue with the context where it is inserted }\end{array}$ \\
\hline $\begin{array}{l}\text { Addressed } \\
\text { issues }\end{array}$ & $\begin{array}{l}\text { - How do group participants communicate? } \\
\text { - How does the group communicate with people, } \\
\text { customers, suppliers, etc.? } \\
\text { - How and how many times a week do the group } \\
\text { usually see, talk and get together? } \\
\text { - What makes difficult the interaction between you } \\
\text { guys? Between you and the customers? } \\
\text { - What facilitates the interaction between you? }\end{array}$ \\
\hline
\end{tabular}

The cooperation aspect and its indicators reflect a composed connection between skill-dialogue (SENNETT 2012; FREIRE 1979) and active welfare (MANZINI 2008), in the divergences that complement and sustain the group, such as catching and releasing, for example.

3. ENGAGEMENT aspect that, Freire (1979) deals with the action-reflection proper to the human existence, of the subject active-conscious action in the world, so, it is linked to its commitment to the world, to the practice of the subject existence in its context; of know the context and recognize it through its action. Collaborating with Freire, Sennett (2013) approaches it as a practice of self-knowledge, where commitment "... lives in the simple recognition that it makes mistakes," which leads to improving its ability.

Table 3. Engagement indicators.

\begin{tabular}{|c|c|}
\hline Indicator & Subject/group skill level \\
\hline Definition & $\begin{array}{l}\text { This indicator tries to understand the group's abilities to } \\
\text { remain united and cohesive, complicit in its processes }\end{array}$ \\
\hline $\begin{array}{l}\text { Addressed } \\
\text { issues }\end{array}$ & $\begin{array}{l}\text { - Which handicraft stages or processes of creation, } \\
\text { production and/or management are under your } \\
\text { responsibility? } \\
\text { - What coincides between what you guys look for as } \\
\text { artisans and what the group seeks with handicrafts? } \\
\text { - How does the group act when you make a mistake? }\end{array}$ \\
\hline Indicator & $\begin{array}{l}\text { Degree of the subject identification with the group and } \\
\text { the group with the context }\end{array}$ \\
\hline Definition & $\begin{array}{l}\text { This indicator deals with the identification of the } \\
\text { differential of the group in its context }\end{array}$ \\
\hline $\begin{array}{l}\text { Addressed } \\
\text { issues }\end{array}$ & $\begin{array}{l}\text { - How do you see the handicrafts development for the } \\
\text { group? } \\
\text { - How does the group see the handicrafts development } \\
\text { for their city? }\end{array}$ \\
\hline
\end{tabular}

This engagement aspect and its indicators represent a composed connection between pleasure-poetry (SENNETT 2012), in the affective-emotional relationship of the hug-sympathy and the encounterempathy, of the family, the neighborhood, the common environment and nature.

\section{Ethnographic incursions-validations}

Talking about the ways of doing of the handmade production group MulheresFatechas goes back to our first moment of intense connection: the technical team arrival in the mangrove. 


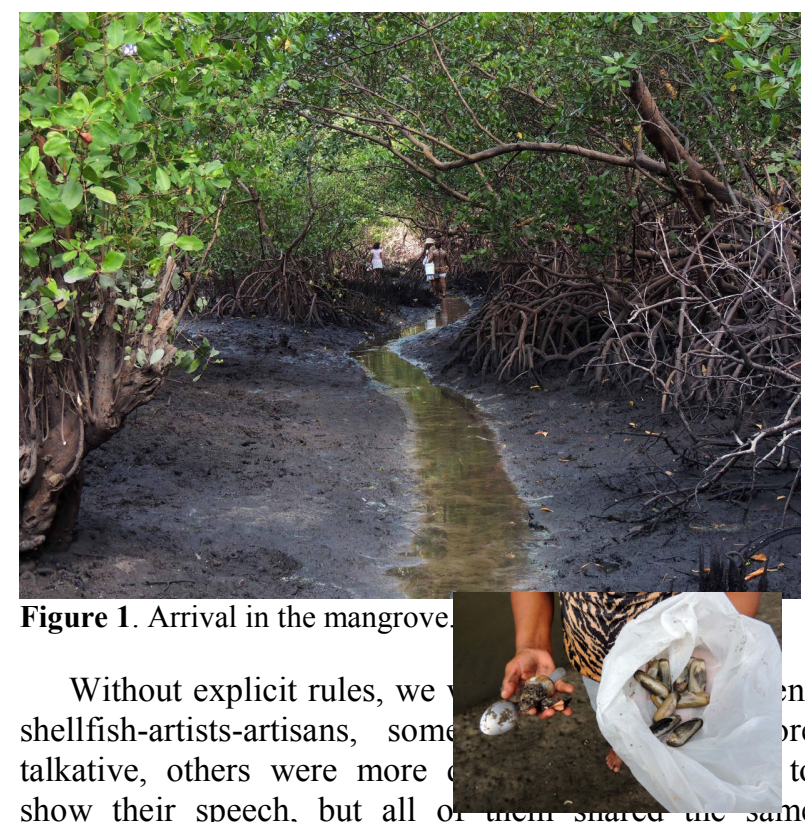

show their speech, but all inspiration and mastery; were our guides; they were our instructors and we were their apprentices.

They showed us how to feel the ground, the mud, in order to identify the crustaceans present there. Sennett (2013) explains that in demonstrating, the master artisan presents a successful act that serves as a result to be achieved, and from the moment the learner starts the experimentation he must discover (in himself) which mechanism (body-imagery) that reaches the master's result (SENNETT 2013). It is in this way that Sennett (2013) brings the understanding that "every good artist sustains a dialogue between practices and concrete ideas", considering that corporal practices are established as a technical development directed and driven by the Imagination (language/medium of expression).

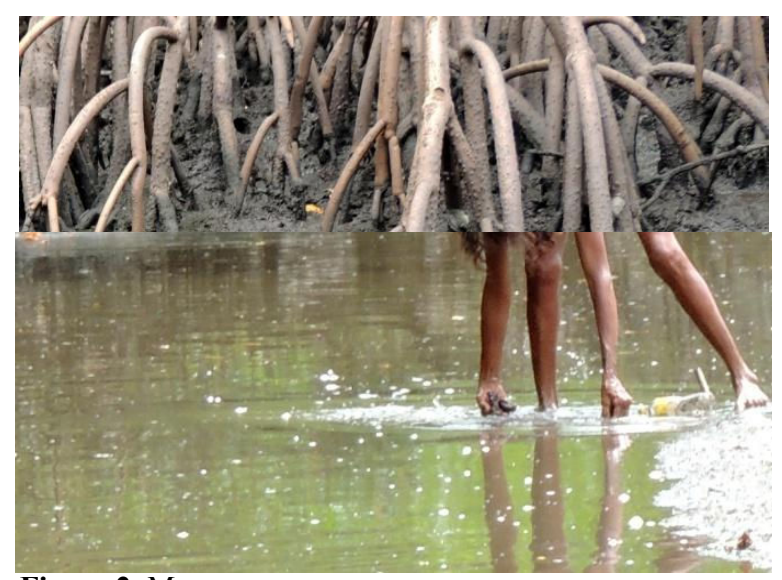

Figure 2. Mangrove woman.

Gradually, we began to "see" the animals, trapped in the mud; to distinguish the textures and pigmentations of that landscape, initially foreign, as well as the movements, tools and postures of the fisherwomen- shellfish in the mangrove. We learned from techniques of shellfish to manufacture of medicines, using from parts of the mangrove to communicate and dye fabrics, recipes to cook the fish and prayers (to the Mangrove Father) that protect the fisherwoman and guarantee the abundance in the fishing/collection.

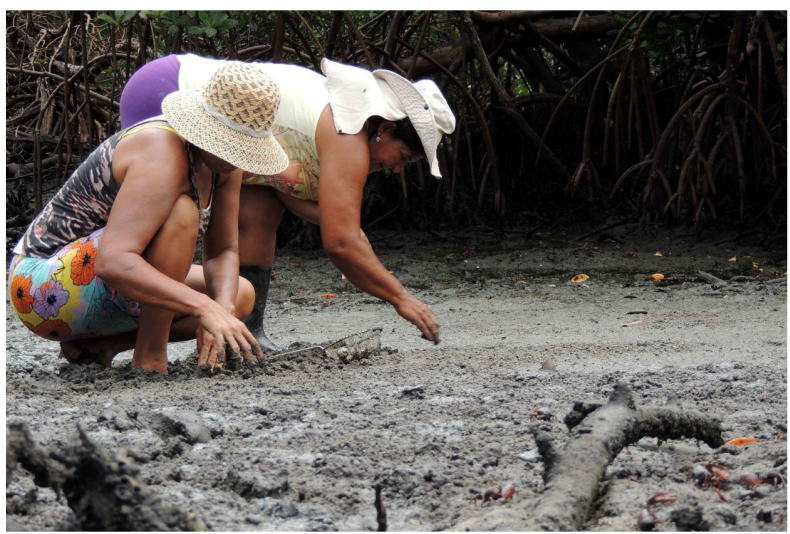

Figure 3. Fisherwomen working.

Most fisherwomen depended on the feet and hands for the technologies used, as well as the precise identification of the location of the crustaceans to be collected. The perception of these places occurred by vision, touch and hearing. The instruments were simple bags, buckets, sacks, hooks, but effective from the experience developed since childhood.

As designers, we were wielding our body from the demonstration speeches of fishermen-shellfish-artistsartisans about their environment, about who they were and how they did to take from the mangrove their nutritional support: emotional/cultural - linked to memory and ancestors; health/financial - linked to food/fish; social - linked to the form of organization and cooperation between them. We were constituting ourselves of their ways of doing, their memories, their imaginaries. In this way, knowledge sharing and learning were mainly related to touch exercises, the look and the importance of listening exercises, the ambiguity of listening, between passivity and activity. In other words, in the exercise of listening (linked to the perception of the senses), our imagination guided and drove our body to perform tasks according to the conditions and restrictions presented in the field.

From so much experience of the mangrove, during all childhood and adolescence, the fisherwomen-shellfishartists-artisans developed their knowledge through the colors, sounds, textures, smells, flavors and nutrients from the mangrove. They improved their skills; they have enlarged their seizure, their imagination and formal and material awareness.

Sennett (2012) says that, this apprehension is seen as a "empowerment", as a "training practice"; As an experience of "studying one's own practice and modulating it from the inside out," which is repeated and adjusted to the person who practices it. According to 
him, "As a person develops his capacity, he changes the content of what he repeats," during the moment that bodily experience is unleashed. In Sennett's words (2013), "In a dialectic between the correct way of doing something and the willingness to experiment through error, the two sides can not be separated" (SENNET 2013). It means to say that the artist-artisan refers to the experience of time through the reflection, in time, about the error, aiming to improve its practice over time. For the sociologist, "handicraft skills are necessary to establish these connections and thus the conscious value of objects "(SENNETT 2013).

Building a bridge with Sennett, Freire (1980) reveals awareness as a test of reality (FREIRE 1980). Thus the training comes from concrete tests that sharpen awareness, which exercise the dialogue between body and mind, between practices and ideas, as we surpass the spontaneous sphere of apprehension of reality.

It was in this movement, of constant exchanges, that the group's knowledge was being developed, configured by a regular practice, configured by rituals.

As we looked at the group, we realized that for each situation there was a way to act, a protocol to follow, defined collectively and/or passed on by generations. There were work divisions obeying the skills and abilities, obeying the knowledge of each member. There was time to fish/collect and times that could not catch some types of clams, crustaceans and fish because of their reproduction; there were ways of fishing/collecting: with their hands, their feet, with instruments. For the accomplishment of the handicraft, there were moments of techniques exchange and transfer, agreed between all the participants. It was part of the group's actions: fishing/collecting shellfish, cleaning and processing fish residues/shells, arranging them by type, size and color, to be pierced and chosen to assemble the products.

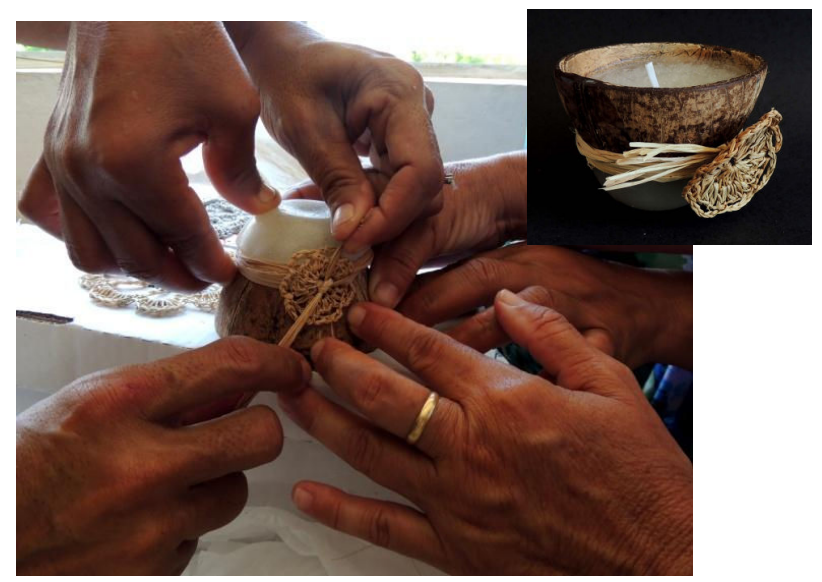

Figure 4. Experimenting together.

At different times, we observed the cooperation that existed during the experimentation moments, where artists-artisans who were testing new products, techniques or ways to sell, for example, sought support from the more experienced. This group movement sometimes showed the fragility and/or flexibility of the same, depending on how they responded to the requests.

It was possible to observe conflicts, coming from different points of view, different ways of doing and learning times. Being these conflicts that triggered the possibilities of improving the interpersonal relationship, when they were able to reach a consensus, as to the labor development, gathering different views, doings, thoughts between themselves.

Sennett (2012) explains, from Montaigne's ${ }^{5}$ work, that dialogic practices - specialized, informal and empathic $^{6}$ - are aspects of the cooperation practice. In addition to the creation and production of the product, the artists-artisans practiced the art of conversation, reflected together and re-invented themselves as a group, "artisanally", for their involvement and cooperation.

The design project has thus become a simulator of experimentations, surrounded by possibilities, conflicts, challenges and overcoming, which have trained and disciplined our bodies to carry out the activities together and to mobilize something.

Still from the project perspective, the time management represented a challenge arisen in the scope of the functionality. We can say that there was a conflicting relationship in the project, between artistscraftswomen and designers, and that this relationship transited between practice and practical, between process and result (SENNETT 2013), "(...) between the conflict of doing well and being able to end "(SENNETT 2013). With a closed schedule, the team had to be precise in certain actions and leverage processes, causing the group to discuss and reflect together, to develop solutions and experiment, to research and act independently of the designers, to reach the expected result. Such conflictual situations experienced in the field, which demonstrated the skills, positioning and rhythm management by artists-artisans and designers, deal with a practical issue "of giving up control - of the mode - over others" (SENNETT 2013). Leaving the fluid process taking advantage of the differences for the subjects and collectivity construction. Therefore, for all those involved, doing (with hands/craft) is linked to a problem/ethical implication regarding the mode: the "letting go" (SENNETT 2013). As an example, the remoteness of the designers team from the field to the

\footnotetext{
5 The philosopher Michel Montaigne (1533-1592), according to Sennett (2012), "was a master of dialogical thinking", and to reflect ways of applying it to everyday cooperation.
}

6 The Empathy is understood as recognition of what the other is doing, unlike sympathy, which is more related to a personal identification with the other (SENNETT 2012). 
end of the project was a moment that required an exercise of release, of detachment from each other; However, it was at this moment that we observed the bonds built: of friendship, complicity and trust between peers.

We realize that the ritualization of group practices continues to modify their experience in a process of awareness and cooperation, constantly updating what Gennep (2011)

"... insinuates the hope of all men in their inexhaustible desire to pass and stay, to hide and to show, to control and to liberate, in this constant transformation of the world and of itself that is inscribed in the verb to live in society" (GENNEP 2011).

Building a bridge between Gennep (2011) and Sennett (2013), we can understand that the ritual signals the transformations of fisherwoman-shellfish-artistsartisans (and designers) in their learning dynamics through the things they do, through "the way how resistance (by repetition) and ambiguity (certaintyuncertainty/right-wrong) can be instructive experiences"(SENNETT 2013) ${ }^{7}$.

Thus, it is the plane of doing that we observe with more clarity the cooperation concept, which here refers to the act that "is involved in the experience of reciprocal pleasure" (SENNETT 2012). And to get this pleasure, the subject needs to be engaged to act with skill.

Through experience we experience something that surrounds and transforms us, which leads us to improve action through experimentation; in this way, cooperation takes place through engagement. According to Sennett (2012),

Curiosity can 'encourage' us to look beyond ourselves. (...) looking backwards creates a social bond better than imagining that others will be reflected in ourselves or doing as if society itself were built as a mirrors hall. But looking out is a skill we must learn. (SENNET 2012)
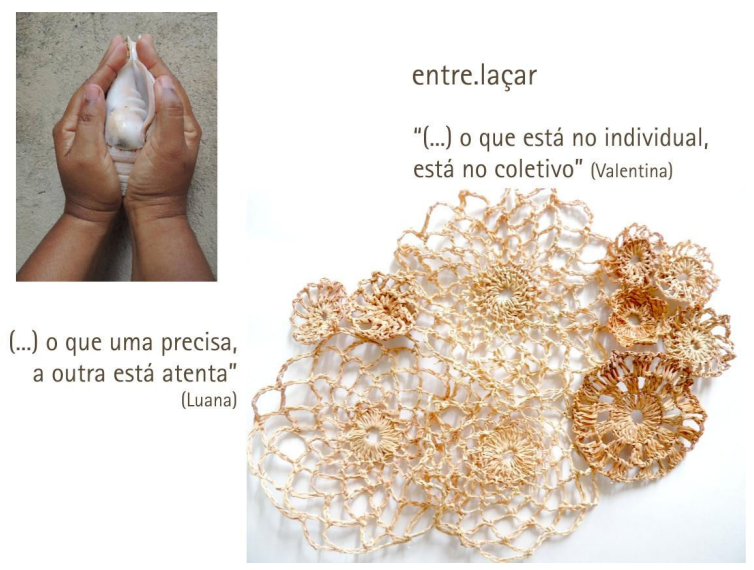

\footnotetext{
${ }^{7}$ Our emphasis
}

Figure 5. Doing poetry.

Engagement presupposes a (pre) disposition and the subject internal mobilization, which affects himself and affects the context, affects the perception of the context by feeling about it. In making poetic, emotions produce meaning (s). It is through the emotion, by memory of parents and grandparents, that the fisherwomenshellfish-artists-artisans justify their stay in the shellfishing. Marks embedded in their bodies, such as cuts, sunburns, provide a discourse that surrounds them with pain/suffering and love/hope of living-working in the mangrove; and unifies them as a group marked by the mangrove. This discourse of physical-emotional marks is contained in the presentation speech of these women as workers, warriors, fighters, artisans, shellfish; as subjects that make/transform their context. In this sense Freire (1979) explains that

The commitment, proper to human existence, exists only in the engagement with reality, from whose "waters" truly compromised men get "wet", soaked. Only then is true the commitment. (Freire 1979)

In Sennett (2013) and Freire (1979), engagement can mean a sort of aura that arises from a retroactive engagement (with partners, with context), so, from praxis and consciousness (articulation between the subject-world-make-reflect).

We can also say that Platão, as quoted by Sennett (2013), pointed to a bridge that links doing and emotion, finding "the etymology of doing, the word poiein, the origin of the concept of ability" (SENNETT 2013). Also being the word that gave rise to poetry. On the other hand, the poetic making starts from the subject's ability when it seeks meaning through the realization in its relation to the world/context. In this act, "(...) All handicraft is a work focused on the quest for quality" (ibid.), so, between the way something must be done and make it work.

We believe that it can be the interlocutors engagement of the field (artists-craftswomen and designers) that makes of each project a poetry inscribed in specific time and space.

\section{Final Considerations}

We believe that the article corroborates with the projects and designers that work in the handicraft area in order to present postures and collaborative paths, in unveiling the participation and responsibility of these professionals, especially in fields of traditional handicraft. We also understand that the promising possibilities of the projects are related to the process, with the involvement/engagement of the design team and the group, with the articulations and conditions of participation and cooperation among all the participants. 
Just as they are linked to creative autonomy and to living with difference, with the divergent.

In this way, the fields dealing with design projects for handicrafts are open lands for designers to research different ways of practicing life, to relate and articulate local resources, to research the most varied mechanisms of collective action, in order to lead us to a more balanced society in its interactions and relations with nature. In other words, they are fields for social innovation, not for innovating, because they are natural processes, structures of lives based on ancestry, memory, etc., but because they present different actions from those that we know and to which we are linked.

\section{References}

FREIRE, P. Educação e mudança. $12^{\mathrm{a}}$ ed. Rio de Janeiro, Paz e Terra, 1979.

. Conscientização: teoria e prática da

libertação: uma introdução ao pensamento de Paulo

Freire / Paulo Freire; [tradução de Kátia de Mello e silva; revisão técnica de Benedito Eliseu Leite Cintra]. - São Paulo, Cortez \& Moraes, 1980.

Pedagogia da autonomia: saberes necessários à prática educativa. São Paulo, Paz e Terra, 1996.

GENNEP, A. Os ritos de passagem: estudo sistemático dos ritos da porta a soleira, da hospitalidade, da adoção, gravidez e parto, nascimento, infância, puberdade, iniciação, coroação, noivado, casamento, funerais, estações, etc. 3. ed. Petrópolis, Vozes, 2011.

MAFFESOLI, M. O tempo das tribos: o declínio do individualismo nas sociedades de massa. $2^{\mathrm{a}}$ ed. Rio de Janeiro, Forense Universitária, 1998.

MANZINI, E. Design para a inovação social e sustentabilidade: comunidades criativas, organizações colaborativas e novas redes projetuais. Rio de Janeiro, E-papers, 2008.

SENNETT, R. Juntos. Rio de Janeiro, Record, 2012. . O Artífice. Rio de Janeiro, Record, 2013. 